\title{
PERILAKU HIGIENE PENGAMBILAN SAMPAH RUMAH TANGGA DI KALISARI PURWOKERTO UTARA KABUPATEN BANYUMAS
}

\section{HYGIENE BEHAVIOR OF HOUSEHOLD WASTE MAKING IN KALISARI PURWOKERTO UTARA BANYUMAS DISTRICT}

\author{
Heryanto \\ Jurusan Kesehatan Masyarakat Fakultas Ilmu-Ilmu Kesehatan \\ Universitas Jenderal Soedirman
}

\begin{abstract}
Efforts to prevent and reduce mortality due to disease, each individual is required to have habits in daily life, namely to carry out personal hygiene in accordance with hygiene and health standards. The work of taking household waste in the Kalisari area has the potential risk of being exposed to various kinds of occupational diseases that every day interact with garbage, so that individual hygiene behavior is needed to prevent the risk of work activities. This study used a qualitative descriptive approach using the technique of determining the purposive sampling and snow ball samples. To obtain data the researcher used in-depth interview and observation techniques, while to obtain valid data information the research used data triangulation, sources and methods. In an effort to explore information about individual hygiene, workers taking household waste researchers used research subjects. The research subjects were 5 workers with one constellation or the data had reached a saturation point and did not vary anymore. From the results of research on the personal hygiene of garbage collection workers, workers have not been able to definitively understand individual hygiene knowledge. The attitude of the workers supports supporting individual hygiene and some have used PPE, namely bood hat shoes. Sarana prsarana at work, not all workers use the complete work attributes, namely PPE. Puskermas Officer in this case sanitarian officer provides counseling in an effort to provide personal hygiene information.
\end{abstract}

Keywords: Behavior, personal hygiene, garbage collection

\begin{abstract}
ABSTRAK
Upaya mencegah dan mengurangi angka kematian akibat penyakit, setiap individu dituntut memiliki kebiasaan dalam kehidupan sehari-hari, yaitu dengan melakukan kebersihan individu sesuai dengan standar kebersihan dan kesehatan. Pekerjaan mengambil limbah rumah tangga di daerah Kalisari memiliki potensi risiko terkena berbagai jenis penyakit akibat kerja yang setiap hari berinteraksi dengan sampah, sehingga perilaku kebersihan individu diperlukan untuk mencegah risiko kegiatan kerja. Penelitian ini menggunakan pendekatan deskriptif kualitatif dengan menggunakan teknik penentuan sampel purposive dan bola salju. Untuk mendapatkan data, peneliti menggunakan wawancara mendalam dan teknik observasi, sedangkan untuk mendapatkan informasi data yang valid, penelitian ini menggunakan triangulasi data, sumber, dan metode. Dalam upaya untuk mengeksplorasi informasi tentang kebersihan individu, pekerja yang mengambil peneliti limbah rumah tangga menggunakan subjek penelitian. Subjek penelitian adalah 5 pekerja didapatkan data bahwa telah mencapai titik jenuh dan tidak berbeda lagi. Dari hasil penelitian tentang kebersihan individu pekerja pengumpul sampah, pekerja belum dapat secara definitif memahami pengetahuan kebersihan individu. Sikap pekerja mendukung mendukung kebersihan individu dan beberapa telah menggunakan APD, yaitu sepatu topi yang bagus. Sarana prsarana di tempat kerja, tidak semua pekerja menggunakan atribut kerja yang lengkap, yaitu APD. Petugas Puskermas salah satunya petugas saniter diharapkan memberikan konseling dalam upaya memberikan informasi kebersihan individu.
\end{abstract}

Kata kunci: Perilaku, kebersihan diri, pengumpulan sampah.

PENDAHULUAN 
Perilaku higiene merupakan salah faktor yang dapat menimbulkan masalah kesehatan, karena berkaitan dengan tata cara dan kebiasaan masyarakat selain juga kondisi lingkungan yang mendukung (Dechi, 2008). salah satu yang menjadi masalah kesehatan di Indonesia adalah perilaku higiene perorangan. Dengan lingkungan yang sehat masyarakat akan dapat berkembang menuju peningkatan derajat kesehatan masyarakat yang setinggi- tingginya (Dekes RI, 2007).

Sumber data tentang profil Kabupaten Banyumas Tahun 2011, menunjukan bahwa 29,925 kasus diare yang dilaporkan. Penyakit tersebut muncul akibat infeksi mikroorganisme patogen yang erat kaitannya dengan higiene. Perilaku higiene perorangan yang baik dapat mencegah timbulnya penyakit dan mengurangi angka kematian akibat penyakit (Lubis, 2006). Perilaku higiene pengambilan sampah rumah tangga yang tidak sehat merupakan perilaku yang beresiko menimbulkan masalah-masalah kesehatan akibat dukungan tempat tinggal.
Perilaku higiene perorangan pengambilan sampah rumah tangga berkaitan dengan faktor pembentukan perilaku. Seperti dikemukan oleh Green, bahwa perilaku itu ditentukan oleh tiga faktor, yaitu faktor predisposisi, faktor pendukung, dan faktor penguat (Notoatmodjo, 2003).

Faktor predisposisi mencakup pengetahuan, sikap dan aktifitas pengambilan sampah rumah tangga tentang higiene perorangan. Faktor pendukung yaitu faktor yang memfasilitasi perilaku higiene pada saat pengambilan sampah rumah tangga. Faktor penguat terkait dengan dengan sikap dan perilaku petugas kesehatan dalam memberikan informasi atau penyuluhan tentang higiene perorangan. Perilaku merupakan respon atau reaksi seseorang terhadap stimulus atau rangsangan dari luar. Perilaku higiene perorangan dipengaruhi faktor sosial demografi, budaya dan psikologis. Budaya dan psikologis terkait higiene perorangan dalam wujud kebiasaan dan persaan dalam konteks penggunaan APD (Juanita, 2003). 
Pekerjaan sebagai pengambil sampah rumah tangga mempunyai resiko besar karena berbagai penyakit akibat aktifitas yang berhubungan dengan sampah, sehingga dibutuhkan higiene perorangan yang baik untuk mencegah resiko tersebut semakin besar. Penyakit yang mencul akibat aktifitas tersebut diakibatkan oleh higiene perorangan yang buruk, diantaranya adalan infeksi parasit, bakteri, virus dan penyakit kulit, sehingga perilaku higiene perorangan pengambilan sampah rumah tangga sangat penting perannya dalam mencegah penyakit (Irianto, 2009).

$$
\text { Sampah rumah tangga }
$$

mengahasilkan lindi atau air sampah yang merupakan sumber pencemaran lingkungan. Lindi adalah zay yang bersifat toksik (racun) dan karsinogenetik (penyebab kanker), sehingga beresiko menimbulkan penyakit akibat kerja bagi para pengambil sampah (Depkes RI, 1997).

Data terkait dengan aktifitas pengambilan sampah rumah tangga di Banyumas pada umumnya mereka akan terpapar penyakit. Penyakit tersebut menunjukan $10,45 \%$ terkena penyakit kulit dan 9,32\%terkena diare. Kedua penyakit tersebut terdapat pada pengambil sampah rumah tangga di wilayah Kalisari Purwokerto Utara Kabupaten Banyumas. Berdasarkan studi pendahuluan, diketahui bahwa para pengambil sampah rumah tangga sering mengalami resiko, seperti luka tertusuk benda tajam dalam kontek dengan aktifitasnya dan menurut para pengambil sampah merupakan hal yang biasa, sehingga penggunaan alat pelindung dianggap kurang penting.

\section{METODE}

Jenis penelitian ini menggunakan pendekatan kualitatif deskripsi dan teknik penentuan sampel dalam penelitian teknik yang dipakai purposivesampling, kemudian untuk eksplorasi informasi data digunakan teknik wawancara mendalam melalui teknik snowball, untuk menentukan jumlah subyek penelitian peneliti menggunakan metode satu rasi, dimana jika informasi data telah memadahi maka penelitian disudahi. Penelitian ini merupakan suatu proses yang mencoba untuk memahami mengenai kompleksitas yang ada 
dalam interaksi manusia (Sarwono, 2006). Dalam konteks perilaku higiene perorangan mempunyai problem yang komplek dan untuk mendapat informasi data yang absah perlu menggunakan pendekatan perspektif emik Bungin, 2007).

Jadi, penelitian ini bertujuan untuk membuat gambaran tentang suatu keadaan secara obyektif (Notoatmodjo, 2005). Penelitian ini menggali informasi data yang bersumber dari subyek penelitian secara emik, apa yang diketahui, dirasakan dan dihayati oleh subyek penelitian. Subyek penelitian dalam penelitian sejumlah 5 orang pekerja mengambil sampah rumah tangga.

\section{HASIL DAN PEMBAHASAN}

\section{Pengetahuan tentang Resiko}

\section{Bagi Kesehatan Pengambil}

\section{Sampah Rumah Tangga}

Pengetahuan merupakan landan untuk melaksanakan sesuatu karena pengetahuan yang merupakan hasil manusia atau hasil tahu seseorang terhadap obyek melalui indra yang dimilikinya, seperti mata, hidung, telinga (Notoatmodjo, 2005). Dengan demikian dapat dikemukakan bahwa pengetahuan seseorang harus dimulai dari tingkat tahu seta didukung oleh informasi-informasi yang membentuk dan diperoleh dari berbagai sumber. Seperti dikemukakan oleh subekti bahwa pengelolaan sampah dengan menggunakan teknologi berbasis $3 \mathrm{R}$ pada masyarakat dan pemilahan organik dan anorganik dikemas kantong plastik, sehingga akan dapat mengantisipasi bahaya bagi kesehatan (Subekti, 2010). Faktor kunci yang menentukan pengetahuan tingkat pendidikan dan jumlah media informasi yang dimiliki ( Mimien, 2016).

Dari hasil wawancara terhadap subyek penelitian, seluruh subyek penelitian telah mempunyai pengetahuan higiene terkait dengan kebersihan diri secara individu. Seperti dikemukakan pekerja pengambil sampah rumah tangga, telah dapat menjelaskan pentingnya menjaga kebersihan hiegene perorangan. Setelah melakukan pekerjaan langsung mandi, cuci tangan sebelum makan dengan menggunakan sabun. Namun terkait dengan penjelasan secara rinci 
dan detail tentang pengetahuan hiegine perorangan secara benar belum mampu menjelaskannya. Subyek penelitian mengartikan hiegene perorang, jika bekerja harus memakaialat pelindung diri, mencakup atribu-atribut seperti sepatu boot, sarung tangan, topi, masker dan kaca mata yang berfungsi melindungi pada saat melakukan aktifitas pekerjaan. Subyek penelitian secara keseluruhan belum dapat menjelaskan secara definit sesuai dengan standar kesehatan higiene perorangan. Pengetahuan perilaku hiegene perorangan seperti dikemukakan oleh Wolf, (2000) mencakup kebersihan kulit dengan cara mandi dua kali sehari, memakai sabun dan menjaga kebersihan pakaian, kebersihan rambut dengan memakai topi pada saat beraktifitas dan kebersihan tangan, kaki, kulit dan kuku dengan cara membersihkan tangan sebelum sebelum dan sesudah makan serta pasca bekerja.

Seperti dikemukakan subyek penelitian: ya....penting mandi dua kali sehari, menggunakan handuk, makan bersilah....seperti cuci tangan dulu sebelum makan, apabila kalau habis kerja langsung cuci tangan dengan sabun, biar bersih lah...dulu pernah lihat di televisi, ya.....sudah lama gitu.

Sependapat dengan Navy, bahwa perilaku hiegene merupakan tindakan pencegahan yang menyangkut tanggung jawab individu untuk meningkatkan kesehatan serta penyebaran penyakit menular, terutama yang ditularkan secara langsung. Dalam konteks pengetahuan para pekerja tersebut secara rinci dan detail belum mampu menjelaskannya, termasuk sumber-sumber penyebaran dan penularan penyakit. Selanjutnya dijelaskan tentang sikap para pekerja pengambil sampah rumah tangga.

\section{Sikap terkait tentang Pekerja Pengambilan Sampah Rumah Tangga}

Sikap tentang $\begin{array}{r}\text { hienene } \\ \text { peroranganterhadap suatu }\end{array}$ obyek
adalah kecenderungan
mendukung atau tida memihak
(Notoatmodjo, 2007). Kondisi seperti
itu mempunyai keterkaitan dengan
pengetahuan seseorang dan
kepentingan terhadap perilaku hidup
bersih dan sehat. Realisasi perilaku
seseorang tidak bisa secara langsung


dapat diketahui, tetapi hanya dapat diinterpretasikan dahulu dari perilaku tertutup (covert behavior).

Dari sumber informasi data yang diperoleh dari subyek penelitian, bahwa pekerja pengambil sampah rumah tangga mengatakan merasa penting tentang hienene perorangan, karena menurutnya bila hiegene perorangan tidak dilakukan maka akan dapat berpotensi tubuh mudah terpapar penyakit. Oleh karena itu, sikap para pekerja pengambil sampah rumah tangga mengindikasikan terkait dengan sikap berupa keinginan untuk menjaga kebersihan perorangan agar tidak terserang penyakit.

Seluruh petugas pengambil sampah rumah tangga, mengatakan bahwa hiegene perorangan itu penting untuk mengantisipasi agar pada saat melakukaqn aktifitas pekerjaan terhindar atau tidak terpapar oleh penyakir yang bersumber dari sampah. Sependapat dengan Azwar, bahwa sikap itu merupakan keteraturan tertentu dalam perasaan (afeksi), pemikiran (kognasi), dan predisposisi tindakan (konasi) seseorang terhadap suatu aspek lingkungan sekitarnya ( Azwar, 1995).

Dari hasil penelitian diperoleh penjelasan terkait sikap, saya punyalah.....pokoknya semua punya seperti alat penutup mulut, sarung tangan, kaca mata tetapi tidak saya pakai soalnya risi, tidak biasa dan tidak punya uang untuk beli pakaian kerja.

Jadi sikap pekerja pengambil sampah rumah tangga telah memiliki hasrat untuk menggunakan alat-alat pelindung untuk dipergunakan pada saat melakukan aktifitas pekerjaannya. Namun ditemui beberapa kendala bagi pekerja terkait pembelian APD karena keterbatasan penghasilan dan ketidak biasaan memakai APD dari para pekerja tersebut. Sependapat dengan Maramis, bahwa sikap itu juga merupakan predisposisi untuk merespon atau bertindak secara positif atau negatif (Maramis, 2006). Subyek penelitian menjelaskan, bahwa pentingnya higiene perorangan bila tidak dijaga maka tubuh akan mudah terserang penyakit, sehingga aktifitas kerja akan terganggu dan pada gilirannya akan mengurangi penghasilan. 


\section{Pemilikan Sarana Prasarana Pekerja Pengangkut Sampah Rumah Tangga}

Pemilikan dan penggunaan sarana prasarana kerja yang dipergunakan subyek penelitian untuk menjaga kebersihan dan kesehatan para pekerja dimaksudkan adalah sarana prasarana yang digunakan pada saat para pekerja melakukan aktifitas pengangkutan sampah rumah tangga untuk dibawa ke TPA. Manfaat perlengkapan APD adalah merupakan upaya para pekerja untuk melindungi diri dan sekaligus menjaga kebersihan perorangan. Dapatlah dikemukakan bahwa para pekerja akan terhindar dari kecelakaan kerja yang dapat mengganggu bagi kesehatan para pekerja itu sendiri.

Dari informasi data yang diperoleh melalui wawancara dan observasi, ternyata belum seluruh pekerja memiliki dan menggunakan alat pelindung diri sesuai standar kesehatan pekerja.

Diperoleh

penjelasan dari subyek penelitian bahwa:

Saya punya kaos tangan, tutup mulut, kaca mata, topi terus....sepatu bot, celana panjang dan baju lengan panjang buat kerja, tetapi teman-teman semua belum menggunakan seperti saya ya.....

Dari informasi data diperoleh penjelasan , bahwa dua orang subyek penelitian telah memiliki dan menggunakan alat pelindung secara lengkap pada saat melakukan pekerjaan mengangkut sampah. Atribut yang digunakan mencakup pekerja menggunakan sepatu boot, sarung tangan, masker, topi dan pakaian lengan panjang serta celana penjang. Sedangkan tiga orang subyek penelitian selama melakukan aktifitas pekerjaan belum menggunakan atribu pelindung secara lengkap, tetapi baru menggunakan topi sebagai pelindung dari sengatan mata hari. Dapat dikemukakn bahwa pekerja pengangkut sampah secra keseluruhan belum memakai alat pelindung diri bahkan ada yang tidak mau memakai beberapa alat pelindung karena dianggap mengganggu atau merasa tidak nyaman. Kondisi seperti ini menggambarkan bahwa seluruh pekerja pengangkut sampah rumah tangga belum mempunyai kesadaran 
bahwa pekerjaan mereka berpotensi membahayakan bagi kesehatan pekerja. Betapa penting menggunaan sepatu boot, sarung tangan, masker, kaca mata, topi dan baju lengan panjang serta celana panjang untuk kebersihan dan kesehatan diri. Kebersihan mencakup kebersiahn tangan, tubuh atau badan, rambut, mulut, tangan, kaki, kulit dan mata pada saat melakukan aktifitas pekerjaan. Sependapat dengan Suti, bahwa alat pelindung diri mempunyai kemampuan yang berfungsi mengisolasi tubuh tenaga kerja dari bahaya di tempat kerja (Suyuti, 2000). Mengacu pada Instruksi Meneteri Tenaga Kerja RI nomor 02/BW/1984 tanggal 31 Agustus 1985 tentang pengesahat Alat Pelindung Diri, maka semua alat pelindung yang diedarkan dan digunakan di seluruh Indonesia. Pekerja dalam melakukan pekerjaannya diharuskan menggunakan sepatu boot melindungi kakiagar terhindar kontak langsung dengan benda-benda tajam yang berbahaya dan terhindar dari air lindi yang bersifat mengandung toksin (racun) dan karsinogenetik (penyebab kanker, sehingga beresiko menimbulkan penyakit (Depkes RI, 1997). Pekerja baru sebatas pemahaman sikap, namun belum sampai pada pemahaman bahwa resiko yang tibul jika pekerja tidak menggunakan alat pelindung. Pekerja juga belum memahami bahwa sampahsampah itu mengandung gas metana dari pembusukan sampah yang bersifat racun dapat membahayakan bagi tubuh manusia ( Harmayani, 2007). Sesuai dengan hasil penelitian ini, ternyata tidak semua pekerja pengangkut sampah rumah tangga hanya sebagian menggunakan APD secara lengkap dan sebagian belum menggunakan APD secara lengkap seperti telah dikemukakan. Selanjutnya dibahas tentang sikap dan perilaku petugas kesehatan sebagai faktor penguat.

\section{Sikap dan Perilaku Petugas Kesehatan}

Sikap dan perilaku petugas kesehatan Puskesmas dalam hal ini sanitarian mempunyai tanggung jawab kepada kesehatan masyarakat. Peran petugas kesehatan mempunyai pengaruh yang penting dalam 
mengupayakan meningkatkan kemampuan masyarakat untuk mengenal potensi mereka sendiri, baik potensi sumber daya manusia maupun sumber daya alam (Machfoedz, 2006). Petugas kesehatan mempunyai peran besar untuk membuat sistem kesehatan dapat lebih mudah diterapkan dan dilaksanakan dalam masyarakat(Notoatmodjo, 2005).

Waduh....saya
dengar ada , tapi
belum pernah
dilakukan
penyuluhan dari
dinas kesehatan,
paling kalau saya
berobat hanya diber
informasi kesehatan
masalah kebersihan
gitu...saja

Petugas kesehatan sanitasi dari Puskesmas belum melakukan fungsinya dan ini dapat dibuktikan belum adanya penyuluhan dalam upaya meberikan informasi tentang hiegiene perorangan. Jadi dapat dikemukakan bahwa fungsi kesehatan yang ada di wilayah Puskesmas Purwokerto Utara belum berpartisipasi secara aktif dan rutin dalam memberikan informasi tentang hiegene perorangan. Kondisi ini akan berpengaruh terhadap pekerja pengangkut sampah rumah tangga. Perlunya kesadaran, pentingnya penggunaan alat-alat pelindung kerja bagi pekerja yang beresiko terpapar penyakit. Kurangnya kesadaran para pekerja terkait dengan kecelakaan kerja, beberapa kejadian kecelakaan pada saat bekerja mengangkut dan membongkar sampah di lokasi TPA. Kejadian kecelakaan kerja disebabkan para pekerja tidak memakai alat pelindung diri, seperti tersayat tangannya dan tertusuk benda tajam.

\section{SIMPULAN DAN SARAN}

Berdasarkan hasil penelitian tentang perilaku hiegene perorangan pengangkut sampah rumah tangga dapat disimpulkan, bahwa pengetahuan pekerja pengangkut sampah rumah tangga belum dapat menjelaskan konsep higiene perorangan, hanya mampu menjelaskan secara garis besar atau belum dapat menjelaskan secara rinci, seperti mandi, cuci tangan sebelum makan, menggosok gigi serta penggunaan alat pengaman kerja yang berfungsi untuk mengantisipasi kontak langsung dengan sampah. 


Pekerja pengangkut sampat
rumah tangga mempunyai sikap
antusias higiene perorangan bagi para
pekerja tersebut merupakan yang
penting dalam upaya menjaga
kesehatan perorangan, namun baru
sebatas sikap atau belum
mengimplementasikan APD seluruh subyek penelitian. Hal ini disebabkan pekerja belum memiliki APD dan hanya dua orang saja yang sudah menggunakan alat pelindung diri.

$$
\text { Pekerja pengangkut }
$$

sampah rumah tangga masih mempunyai keterbatasan untuk memiliki dan menggunakan sarana prasarana dalam upaya menjaga kebersihan perorangan . Tidak semua pekerja tersebut memiliki dan menggunakan sarana dan prasarana yang lengkap, seperti sepatu boot, sarung tangan, masker, kaca mata, baju khusus kerja dan topi.

Fungsi petugas kesehatan dalam hal ini sanitarian Puskesmas masih belum melaksanakan fungsinya secara rutin melakukan penyuluhan tentang higiene perorangan pada pekerja pengangkut sampah rumah tangga di wilayah Kalisari Kecamatan
Purwokerto Utara Kabupaten Banyumas.

Saran, perlu pemberdayaan upaya meningkatkan pengetahuan tentang hiegene perorangan pada pekerja pengangkut sampah rumah tangga dan meningkatkan kesadaran agar dapat memahami bahwa kebersihan dan kesehatan merupakan hal penting bagi para pekerja tersenut. Upaya merealisasiakan higiene perorangan para pekerja pengangkut sampah rumah tangga, oleh karena itu perlu dilakukan penyuluhan oleh petugas sanitarian dari Puskesmas.

\section{DAFTAR PUSTAKA}

Azwar. S. 1995. Sikap Manusia Teori dan Pengukurannya. Penerbit Pustaka Pelajar.

Bungin, B. 2007. Analisis Data Penelitian Kualitatif. PT. Radja Gravindi Persada. Jakarta.

Dachi, G. 2008. Perilaku Ibu Pemulung Higiene Perorangan di Lingkungan II Kelurahan Sei Agul Kecamatan Medan Barat. Tahun 2008. Skripsi FKM-USU. http://repository. Usu.ac.id/bitstream/123456789/23980/ Chaper\%201. Pdf. Diakses tanggal 17 Mei 2011.

Depkes RI, 2007. Pedoman Pelatihan Pembinaan Perilaku Hidup Bersih dan Sehat di Rumah Tangga. Departemen Kesehatan RI. Jakarta. , 1987. Pembuangan Sampah. Akademi Penilik Kesehatan Teknologi Sanitasi. Jakarta.

Dwiyanti, B. 2011. Model Peningkatan Partisipasi Masyarakatdan Penguatan Energi Dalam Pengelolaan Sampah 
Perkotaan. Jurnal Ekonomi Pembangunan. Vo. 12 2:239-256

Juanita,2005. Program Perilaku Hidup Bersih dan Sehat (PHBS) Studi Kasus di Kabupaten Bantul. Jurnal Manajemen Pelayanan Kesehatan ISSN1410-6515. Vol. 08. Nomor 03/Sep. 2005. 173-174. Harmayani, K. 2007. Pencemaran Air Tanah Akibat Pembungan Limbah Domestik di Lingkungan Kumuh. Jurnal Pemukiman Natah Edisi 5. http//ejournal.unud.ac.id/abstrak/micros oft word-4. Diana-konskt-rumah kumuh.pdf. Diakses 12 Mei 2011.

Irianto, K. 2009. Parasitologi: Berbagai Penyakit yang Mempengaruhi Kesehatan Manusia. Yrama Widya. Jakarta.

Lubis, S. 2006. Hubungan higiene Perorang Pemulung Makanan Sisa dengan Infeksi Kecacingan di Kelurahan Padang Bulan Medan. Tahun 2006. Skripsi . FKM-USU. Medan.http://repository.usi.ac.id/bitstre am/123456789/16352/2/2/Refence. Pdf. Diakses tanggal 10 Mei 2011.

Machfoedz, I. 2006. Pendidik Kesehatan Bagian dari Promosi Kesehatan. Penerbit Fitrayama. Yogyakarta.

Maramis. 2006. Ilmu Perilaku Dalam Pelayanan Kesehatan, Penerbit Airlangga University Press. Surabaya.

Mimien, H. 2016. Keterkaitan Sosial, Ekonomi, Pengaetahuan dan Sikap dengan Manifestasi Perilaku Ibu Rumah Tangga dalam Pengelolaan Sampah tangga di Surabaya. Jurnal Ilmu Pendidikan UNP ISSN: 02159643 Vol 10 No 2:1-11

Notoatmodjo. 2003. Pendidikan dan Perilaku Kesehatan. Penerbit Rineka Cipta, Jakarta.

Puspitawati, Y dan Mardwi R. 2012. Kajian Pengelolaan Masyarakat Berbasis Masyarakat dengan Konsep 3R di Kelurahan Larangan Kota Cirebon, Jurnal Pengembangan Wilayah dan Kota, Biro Penerbit Planologi Undip. Vo. 8 (4): 359-359. . 2005. Metode Penelitian Kualitatif dan Kuantitatif.Graha Ilmu. Yogyakarta.

. 2007. Pengantar Pendidikan Kesehatandan Ilmu Perilaku Kesehatan. Andi Offset. Yogyakarta.

Sarwono, S. 2006. Sosiologi Kesehatan. Gadjah Mada University Press. Yogyakarta.

Sayuti, M. 2000. Alat Pelindung Diri Dalam Kumpulan Makalah Hyperkes: 4. Universitas Gadjah Mada. Yogyakarta.

Nasry, N. 1997. Pengantar Epidemiologi Penyakit Menular. Rineka Cipta Aksara. Jakarta.

Wolf, L. V. 2000. Dasar-Dasar Ilmu Keperawatan. Penerbit Gunung Agung. Jakarta. 